\title{
General 1-D hydrogeological model for temporal near-surface loess saturation assessment for the needs of radon potential mapping
}

\section{Общ 1-D хидрогеоложки модел за времева оценка на наситеността на приповьрхностната част на льосовия комплекс във времето за нуждите на картиране на радоновия потенциал}

\author{
Sava Kolev \\ Сава Колев \\ Geological Institute, BAS, Acad. G. Bonchev str., bl. 24, Sofia; E-mail: sava_kolev@geology.bas.bg
}

\begin{abstract}
Radon gas has high mobility and is driven by advection and diffusion with the soil gas throughout connected and water-unsaturated pores and/or cracks in permeable rocks and soils. Hence the radon potential of the area could be dependent on not only geology as a constant source of radon but also from the changes of the saturation state of the ground. The loess complex, characterized by its permeability and usual state of unsaturation, covers $10 \%$ of the Bulgarian territory. The study deals with the principles of unsaturated domain modeling. An attempt of generic vertical infiltration model coinciding with the most upper part of loess vadose zone was performed.
\end{abstract}

Keywords: unsaturated loess complex, radon gas, permeability, HYDRUS-1D.

\section{Introduction}

Radon is a naturally occurring radioactive heavy noble gas, decay product of ${ }^{226} \mathrm{Ra}$, which is a member of ${ }^{238} \mathrm{U}$ chain. The main source of radon in a building is soil and rocks on which the buildings were situated. Radon exposure is responsible for approximately half of the total annual background radiation exposure (UNCEAR, 2000). For many people, ${ }^{222} \mathrm{Rn}$ is an important source of exposure, which, in principle, can be controlled to some extent (Ivanova et al., 2019). Radon gas has high mobility and is driven by advection and diffusion with the soil gas throughout connected and water-unsaturated pores and/or cracks in permeable rocks and soils. Hence the radon potential of the area could be dependent on not only geology as a constant source of radon but also from the changes of the saturation state of the ground. It is due to the fact that the presence of liquid and gas fluids decreases the cross-sectional area available for the flow of each other. In Bulgaria, studies for the evaluation of the radon geogenic potential, applying the different approaches over the whole territory are carried on nowadays at relatively general geological spatial schemes (Ivanova et al., 2019). Review of the hydrogeological investigations, which can be related to radon potential were made by Valchev et al. (2020) and Kunovska et al. (2021).

The loess complex, characterized by its permeability and usual state of unsaturation, covers $10 \%$ of the Bulgarian territory (Evlogiev, 2019), thus there is a need for quantitative assessment of the saturation state, even on a daily base in order to estimate the radon potential correctly. The more so as, the permeability is one of the key factors in the radon risk assessment (Neznal, Neznal, 2005; Benavente et al., 2019). One modern approach for such assessment is computer modeling based on the convective-dispersion equation with the addition of evapotranspiration models (e.g. Šimůnek, Bradford, 2008; Šimůnek et al., 2013; Šimůnek, 2015). In Bulgaria, there are few studies concerning the unsaturated state of the near-surface sediment de- 
posits (e.g. Benderev et al., 2015; Antonov et al., 2018), including the possibility of daily saturation of the most upper layers (e.g. Antonov et al., 2019; Gerginov et al., 2020). On the other hand, there are particular field studies, investigating the hydraulic characteristics (parameters) of the loess in the vadose zone and the moisture dynamics due to precipitation rates in Northeastern Bulgaria (Mallants et al., 2007; Antonov et al., 2012; Gerginov et al., 2018). The current study is an attempt to elaborate a generic model for evaluation of the near surface loess complex variably state of saturation.

\section{Materials and methods}

The uniform water movement in a partially saturated rigid porous medium is described by a modified form of the Richards equation, using the assumptions that the air phase plays an insignificant role in the liquid flow process and that water flow due to thermal gradients can be neglected (Šimůnek et al., 2013). The resolving of the Richards equation requires the knowledge of two nonlinear functions, namely the soil water retention curve $\theta(h)$ and the hydraulic conductivity function $K(h)$. One of the most popular and endorse models, empirically describing these functions is developed by van Genuchten (van Genuchten, 1980) based on the statistical pore size distribution of Mualem (1976).

According to the van Genuchten model, if the five hydraulic characteristic parameters, namely $\theta_{r}$, $\theta_{s}, \alpha, n$ and $K_{s}$ are known, the two functions $\theta(h)$ and $K(h)$ could be described (van Genuchten, 1980). The values of these parameters for a relevant soil can be determined directly by field and/or laboratory hydraulic tests or estimated indirectly through prediction from more easily measured data based upon quasi-empirical models (Antonov et al., 2012).

In addition, the numerical solution of the Richards equation requires knowledge of the initial distribution of the pressure head within the flow domain, i.e. so-called initial and boundary conditions. For example, in HYDRUD computer program the surface boundary (i.e. upper boundary condition) is exposed to atmospheric conditions. The potential fluid flux across this interface is controlled exclusively by external conditions. However, the actual flux depends also on the prevailing (transient) soil moisture conditions near the surface. The soil surface boundary condition may change from a prescribed flux to a prescribed head type condition and vice-versa (Šimůnek, 2015). A free drainage (zero pressure head gradient) boundary condition is usually specified at the bottom of the soil profile (i.e. lower boundary condition). This boundary condition assumes that the groundwater table is deep below the considered soil profile and that the bot- tom flux is driven only by gravity (Šmůnek, 2015). Finally, actual daily infiltration rate, i.e. actual flux (rain precipitation minus actual evapotranspiration) can be determined by using some of the well-known equations describing evapotranspiration rates, e.g. Hargreaves (e.g. Hargreaves, 1994) or Penman-Monteith (e.g. Monteith, Unsworth, 1990) formulas.

\section{Result and discussion}

Based on one of the main properties of the Bulgarian loess complex, i.e. its predominant vertical hydraulic coefficient in vertical direction, a vertical $1 \mathrm{D}$-profile model is being concerned as the most suitable one. In addition, one-dimensional model is proposed and been suitable because of the observed downward water percolation of the alluvial deposits (Antonov et al., 2019). The loess domain will be characterized for each of its specific layers loess and fossil soils sediments deposited during the different glacial and interglacial stages (Evlogiev, 2019) with the respective five hydraulic parameters for each layer. Such schematizations will be in accordance with the existing or newly acquired field observation data using the information on the sediment layers' depth. The upper boundary condition represents the number of time-variable boundary records, i.e. the precipitation records (existing or newly acquired) and the bottom (lower) boundary condition is set to free drainage. Elaborated like that the model allows to be applied for the near-surface estimation of the moisture dynamics in relatively tick loess sediments (more than 2 meters), which in general covers the most part of the Bulgarian loess complex (Evlogiev, 2019). In case of the opposite (less than 2 meters depth) the model should take into account the possibility of a groundwater level at the bottom of the profile. The initial condition is arbitrary set to pressure head of $-100 \mathrm{~cm}$. The model could be implemented in any existing numerical code for unsaturated modeling allowing the implementation of evapotranspiration rates, e.g. VS2DI, HYDRUS, etc. For the further assessment of the saturation state of the near-surface loess complex HYDRUS-1D code will be used.

\section{Conclusion}

A generic vertical infiltration model, coinciding with the most upper part of loess vadose zone was elaborated. The model will be applied for the parts of the loess complex with more than 2 meters tick in Bulgaria. Implementing the following parameters as daily precipitation rates, temperature, and the specific hydraulic parameters of the loess layers will allow estimating at a reliable degree the state 
of variable saturation and thus to assess the radon potential at a specific site.

Acknowledgements: This study is supported by the National Science Fund of Bulgaria, in the framework of Grant No КП-06-H37/22/07.12.2019.

\section{References}

Antonov, D., D. Karastanev, D. Mallants. 2012. Determination of soil hydrological parameters of a multi-layered loess complex using HYDRUS-2D and field infiltration experiments. - C. R. Acad. bulg. Sci., 65, 1, 1717-1724.

Antonov, D., K. Nakamura, T. Kotsev, V. Stoyanova, R. Kretzschmar. 2018. Application of hydrus-1D for evaluation of the vadose zone saturation state in connection with arsenic mobilization and transport in contaminated river floodplain - Ogosta Valley case study, NW Bulgaria. Proc. 18th Intern. Multidisciplinary Sci. GeoConference "SGEM 2018", 18, 1.2, 83-90; https://doi.org/10.5593/ sgem2018/1.2/S02.011.

Antonov, D., T. Kotsev, A. Benderev, N. van Meir, P. Gerginov, V. Stoyanova, E. Tcherkezova. 2019. Estimating the moisture regime in variably-saturated arsenic contaminated alluvial sediments by using HYDRUS-1D with daily meteorological data. - Eur. J. Geogr., 10, 2, 42-55.

Benavente, D., J. Valdés-Abellán, C. Pla, E. Sanz-Rubio. 2019. Estimation of soil gas permeability for assessing radon risk using Rosetta pedotransfer function based on soil texture and water content. - J. Environ. Radioact., 208-209, 105992; https://doi.org/10.1016/j.jenvrad.2019.105992.

Benderev, A., P. Gerginov, D. Antonov, N. van Meir, R. Kretzschmar. 2015. Conceptual hydrogeological model of the Ogosta river floodplain (Western Balkan, Bulgaria) and its application for predicting of groundwater contamination with arsenic. - Proc. 18th Intern. Multidisciplinary Sci. GeoConference "SGEM 2015", 2, 1, 195-202; https://doi. org/10.5593/SGEM2015/B12/S2.026.

Evlogiev, Y. 2019. Quaternary Geology and Geomorphology of the Danube Plain. Assessment of Neotectonic Conditions at Nuclear Facilities. Sofia, Acad. Publ. House "Prof. M. Drinov", 268 p. (in Bulgarian with English abstract).

Gerginov, P., T. Orehova, V. Petrova, D. Antonov. 2018. Moisture regime in the upper part of the loess complex in NorthEastern Bulgaria. - Rev. Bulg. Geol. Soc., 79, 3, 139-140.

Gerginov, P., D. Antonov, A. Benderev, V. Stoyanova, T. Kotsev. 2020. Analysis and prognosis of the aqueous migration of arsenic based on complex study of Ogosta River valley`s hydrogeological elements (at specific floodplain site). - C. R. Acad. bulg. Sci., 73, 10, 1409-1415; https:// doi.org/10.7546/CRABS.2020.10.10.
Hargreaves, G. H. 1994. Defining and using reference evapotranspiration. - J. Irrig. Drain. Eng., 120, 6, 1132-1139; https:// doi.org/10.1061/(ASCE)0733-9437(1994)120:6(1132).

Ivanova, K., Z. Stojanovska, B. Kunovska, N. Chobanova, V. Badulin, A. Benderev. 2019. Analysis of the spatial variation of indoor radon concentrations (national survey in Bulgaria). - Environ. Sci. Pollut. Res., 26, 6971-6979; https:// doi.org/10.1007/s11356-019-04163-9.

Kunovska, B., M. Trayanova, M. Mutovska, S. Valchev, B. Mihaylova. 2021. Review of investigations related with the vadose zone's variable state of saturation in connection with the assessment of the radon potential in Bulgaria. - Geologica Balc., 50, 2, 47-51; http://doi.org/10.52321/ GeolBalc.50.2.47.

Mallants, D., D. Karastanev, D. Antonov, J. Perko. 2007. Innovative in-situ determination of unsaturated hydraulic properties in deep loess sediments in North-West Bulgaria. - Proc. 11th Intern. Conference Environmental Remediation and Radioactive Waste Management "ICEM'07", 733-739; https://doi.org/10.1115/ICEM2007-7202.

Monteith, J. L., M. H. Unsworth. 1990. Principles of Environmental Physics. Oxford, Elsevier, 2nd Ed., 291 p.; https:// doi.org/10.1002/qj.49712052015.

Mualem, Y. 1976. A new model for predicting the hydraulic conductivity of unsaturated porous media. - Water Resour. Res., 12, 513-522.

Neznal, M., M. Neznal. 2005. Permeability as an important parameter for radon risk classification of foundation soils. Ann. Geophys., 48, 1, 175-180; https://doi.org/10.4401/ag3192.

Šimůnek, J. 2015. Estimating groundwater recharge using HYDRUS-1D. - Engineering Geology and Hydrogeology, 29, $25-36$.

Šimůnek, J., S. A. Bradford. 2008. Vadose zone modeling: introduction and importance. - Vadose Zone J., 7, 2, 581586; http://doi.org/doi:10.2136/vzj2008.0012.

Šimůnek, J., M. Šejna, H. Saito, M. Sakai, M. Th. van Genuchten. 2013. The Hydrus-1D Software Package for Simulating the Movement of Water, Heat, and Multiple Solutes in Variably Saturated Media, Version 4.17. Riverside California, University of California Riverside, $343 \mathrm{p}$.

UNSCEAR. 2000. Sources and Effects of Ionising Radiation. Vol. 1, ann. B, New York, United Nations, 98 p.

Valchev, S., M. Trayanova, B. Kunovska, B. Mihaylova, M. Mutovska. 2020. Analysis of the research activities in Bulgaria related to evaluation of the degree of water saturation in the near-surface layer in connection with the assessment of the radon potential. - Rev. Bulg. Geol. Soc., 81, 3, 233-234.

van Genuchten, M. Th. 1980. A closed-form equation for predicting the hydraulic conductivity of unsaturated Soils. Soil Sci. Soc. Am. J., 44, 892-898; https://doi.org/10.2136/ sssaj1980.03615995004400050002x. 